\title{
ANTITUSSIVE ACTIVITY ASSAYOF SAGE (LANTANA CAMARA L.)LEAVES BASED ON THE BREATHING PATTERN OF MALE GUINEA PIGS USING ADOBE AUDITION 1.5 PROGRAM
}

\author{
WA ODE YULIASTRI ${ }^{*}$, ANDREANUS SOEMARDJI' ${ }^{2}$, MUS IFAYA ${ }^{1}$ \\ 1Department of Pharmacy, STIKES Mandala Waluya, Kendari, Indonesia, ${ }^{2}$ Pharmacology Clinical Pharmacy Research Group, School of \\ Pharmacy, Bandung Institute of Technology, Bandung, Indonesia \\ Email: waodeyuliastri@yahoo.com \\ Received: 22 May 2017, Revised and Accepted: 22 Jul 2017
}

\begin{abstract}
Objective: The present study was aimed to assay antitussive activity of Sage (Lantana camara L.)leaves

Methods: Antitussive Assay was conducted based on The Breathing Pattern of Male Guinea Pigs Using Adobe Audition 1.5 Program.

Results: Comparison of the frequency of breathing patterns guinea pig groups sage (Lantana camara L.) leaves water fraction at a dose of 4.58 $\mathrm{mg} / \mathrm{kg}$ bw dose of $9.17 \mathrm{mg} / \mathrm{kg}$ bw and doses of $18.35 \mathrm{mg} / \mathrm{kg}$ bw statistically significantly different results (p<0.05), as well as the ratio of intensity of the breathing pattern of the guinea pig. As for the water extract, significant differences in the frequency comparison guinea pig respiratory pattern is only shown at a dose of $18.35 \mathrm{mg} / \mathrm{kg}$ bw on the other side for its intensity did not show significant differences (p<0.05).
\end{abstract}

Conclusion: Ethanol extract of sage leaves in the form of three fractionation (ethyl acetate, $n$-hexane, and water) can improve the breathing pattern guinea pig cough, especially at a dose of $18.35 \mathrm{mg} / \mathrm{kg}$ bw.

Keywords: Antitussive activity, Sage (Lantana camara L.)leaves, The frequency of breathing pattern, The breathing pattern

(C) 2017 The Authors. Published by Innovare Academic Sciences Pvt Ltd. This is an open access article under the CC BY license (http://creativecommons.org/licenses/by/4.0/) DOI: http://dx.doi.org/10.22159/ijcpr.2017v9i5.22154

\section{INTRODUCTION}

Cough is an important defensive reflex (response) that enhances the clearance of secretions and particles from the airways and protects the lower airways from the aspiration of foreign materials. Cough is a very common symptom observed in many diseases other than those affecting the respiratory system [1]. Cough reflex is a multifaceted, precisely timed, a neuromuscular phenomenon characterized by the precise concurrent and sequential coordination of the activation patterns of the diaphragm, various muscle groups of the chest wall, cervical muscles, abdominal muscles, laryngeal abductor and adductor muscles, medullary and higher cortical regions of the brain. cough response is due to stimulation of a mechanically-sensitive cough receptor, Both the chemically-and mechanically-sensitive airway nerves take part in mediating the cough reflex and establishing synapses in the brain [2]. Cough is one of the most common symptoms for which patients seek medical attention from primary care physicians and pulmonologists [1].

Herbal products have gained increasing popularity in the last decade, and are now used by approximately $20 \%$ of the population. Herbal products are complex mixtures of organic chemicals that may come from any raw or processed part of a plant, including leaves, stems, flowers, roots, and seeds [3]. The enduring popularity of herbal medicines may be explained by the tendency of herbs to work slowly, usually with minimal toxic side effects [4].

Herbal medicine frequently used in Indonesia as cough therapy is Sage (Lantana camara L.) leaves. Sage (Lantana camara L.) leaves is a medicinal aromatic plant that belongs to the family Verbenaceae and occurs in most parts of the world as an evergreen notorious weed species. Recent studies revealed that leaf extracts and essential oil of Sage (Lantana camara L.) leaves possess larvicidal activities, antioxidant, anti-inflammatory, analgesic, antidiabetic, hypolipidemic, anthelmintic, cytotoxic, wound healing, and antipyretic properties [5-11].

The present study was aimed to assay the cough therapy of Sage (Lantana camara L.) leaves as antitussive on guinea pig using Adobe audition 1.5 software.

\section{MATERIALS AND METHODS}

\section{Collection of sample}

Sage (Lantana camara L.) leaves were obtained from Muna Region, Southeast Sulawesi, Indonesia. The Plant Material Was determination by SITH Bandung Technology Institute.

Animals

The Male guinea pigs with body weight 250-500 g were selected for this research.

\section{Preparation of extract}

Dried Sage (Lantana camara L.) leaves were extracted with reflux method using Technical grade ethanol. The concentrated ethanolic extract was suspended in a minimum amount of water and then fractionated with hexane and ethyl acetate respectively. In each case, the extract was concentrated under reduced pressure.

\section{Phytochemical screening}

The presence of various phytochemical constituents such as alkaloids, saponins, flavonoids, phenolics, tannins, steroids, and terpenoids was screened qualitatively by using standard procedures

\section{Antitussive assay}

Antitussive Assay was conducted using Adobe Audition 1.5 Programaccording [12]. The guinea pig males were divided into several groups; negative control, positive control (aerosol citric acid $10 \%)$, And the test group which divided into three doses group, $4.588 \mathrm{mg} / \mathrm{kg} \mathrm{bw}, 9.176 \mathrm{mg} / \mathrm{kgBw}, 18.352 \mathrm{mg} / \mathrm{kgbw}$ and comparison group of drugs used in this study is dextromethorphan $0.5 \mathrm{mg} / \mathrm{kg}$ bw, each group was given aerosol citric acid $10 \%$ as cough induction.

\section{RESULTS AND DISCUSSION}

Phytochemical screening

Phytochemical screening of the L. Camara Leaves extract shows the presence of Alkaloid, flavonoid, saponin, Tannin, kuinon, and Steroid/triterpenoid. 
Table 1: Result of phytochemical screening of the $L$. Camara leaves extract

\begin{tabular}{llll}
\hline No & Compound & Extract \\
\hline 1. & Alkaloid & + \\
2. & Flavonoid & Saponin & + \\
3. & Tannin & + \\
4. & Kuinon & + \\
5. & Steroid/Triterpenoid & + & \\
6. & & + \\
\hline
\end{tabular}

\section{Antitussive assay}

Antitussive activity test is based on the breathing pattern guinea pig artificial cough swab ethanol extract of sage (Lantana camara L.) by treating the water fraction, ethyl acetate and n-hexane, a dose of $4.58 \mathrm{mg} / \mathrm{kg} \mathrm{bw} ; 9.17 \mathrm{mg} / \mathrm{kg}$ bw and $18.35 \mathrm{mg} / \mathrm{kg}$ bw. Comparison of the frequency of breathing patterns guinea pig artificial water fraction groups sage dose of $4.58 \mathrm{mg} / \mathrm{kg} \mathrm{bw}$ and a dose of $9.17 \mathrm{mg} / \mathrm{kg}$ bw have the result was not significant $(\mathrm{p}<0.05)$ at a dose of $18.35 \mathrm{mg} / \mathrm{kg}$ bw show results significantly different from the positive control. Comparison of the guinea pig cough frequency artificial breathing patterns on the fraction of ethyl acetate and n-hexane at a dose of $4.58 \mathrm{mg} / \mathrm{kg}$ bw, a dose of 9.17 $\mathrm{mg} / \mathrm{kg} \mathrm{bw}$, and a dose of $18.35 \mathrm{mg} / \mathrm{kg}$ bw statistically significantly different results. It is evident from the very significant differences when compared with the control group tested positive after statistics (can be seen in table 1, 2 and 3). This emphasis on cough frequency is already underway from the first period to fourth period of observation, seen that improvement guinea pig cough frequency artificial breathing pattern.

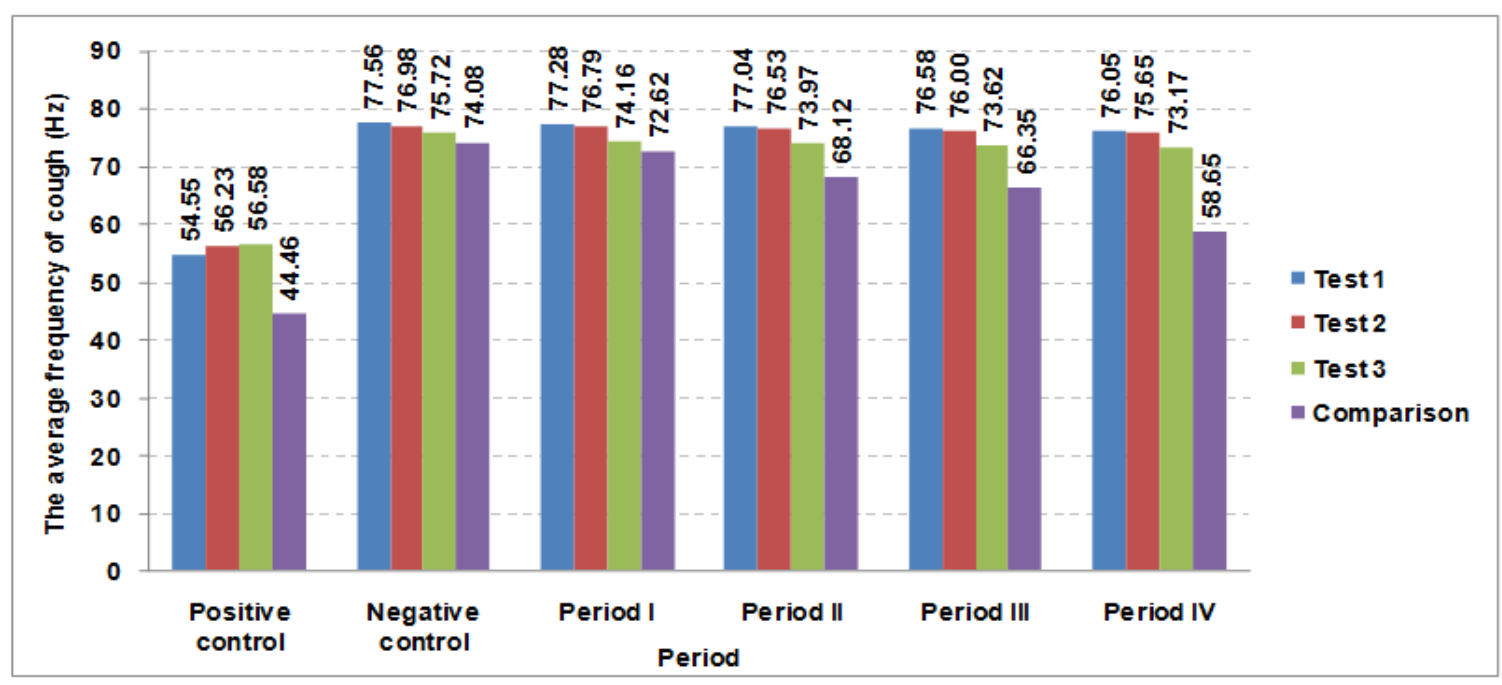

Fig. 1: Changes in the respiratory of guinea pigs cough with water fraction. 1) Positive control (CMC Na. 1\%); 2) negative control (Citrit acid 10\%); 3) period I (Test extract+induction in the minutes 0-15); 4) period II (Test extract+induction in the minutes 15-30); 5) period III (Test extract+induction in the minutes to 30-45); 4) period IV (test extract+induction in the minutes to 45-60)

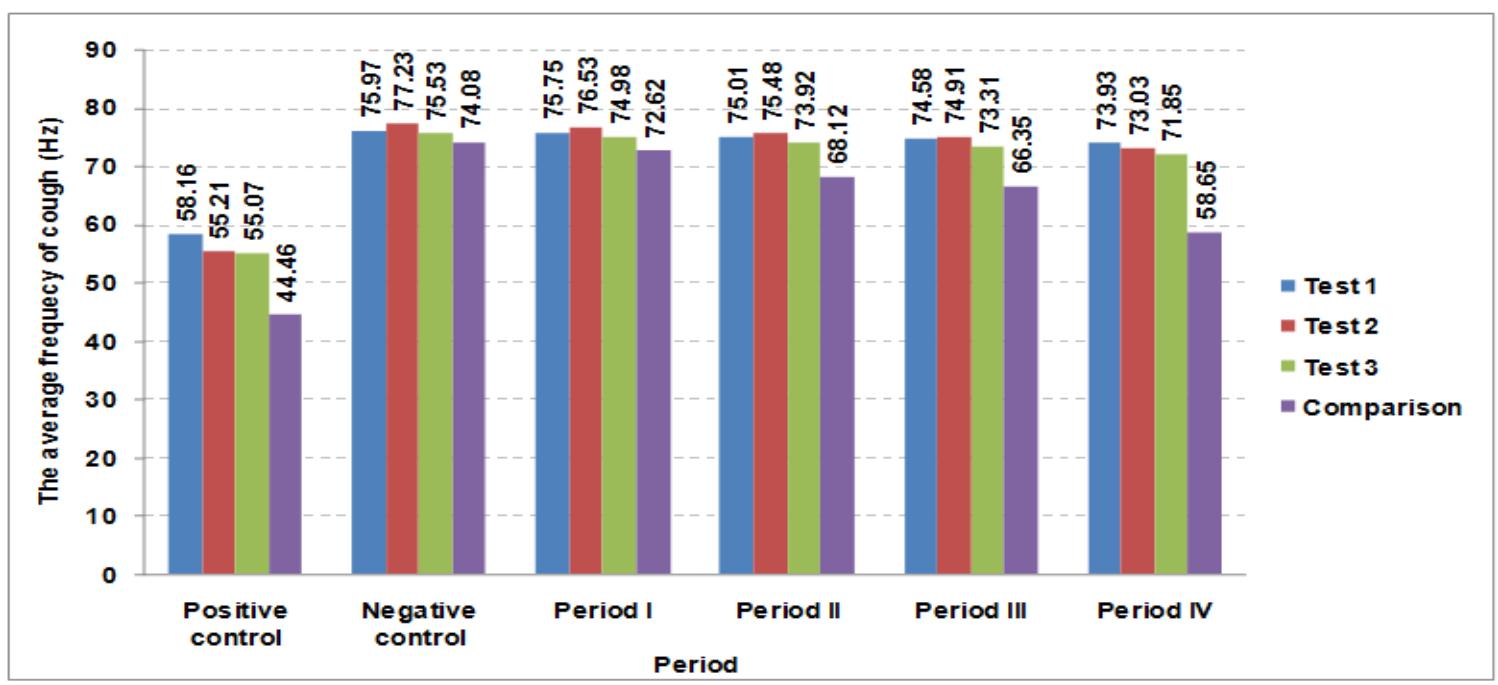

Fig. 2: Changes in the respiratory of guinea pigs cough with ethyl acetat fraction.1) Positive control (CMC Na. 1\%); 2) negative control (Citrit acid 10\%); 3) period I (Test extract+induction in the min 0-15); 4) Period II (Test extract+induction in the min 15-30); 5) period III (Test extract+induction in the min to $30-45$ ); 4) period IV (Test extract+induction in the min to 45-60) 


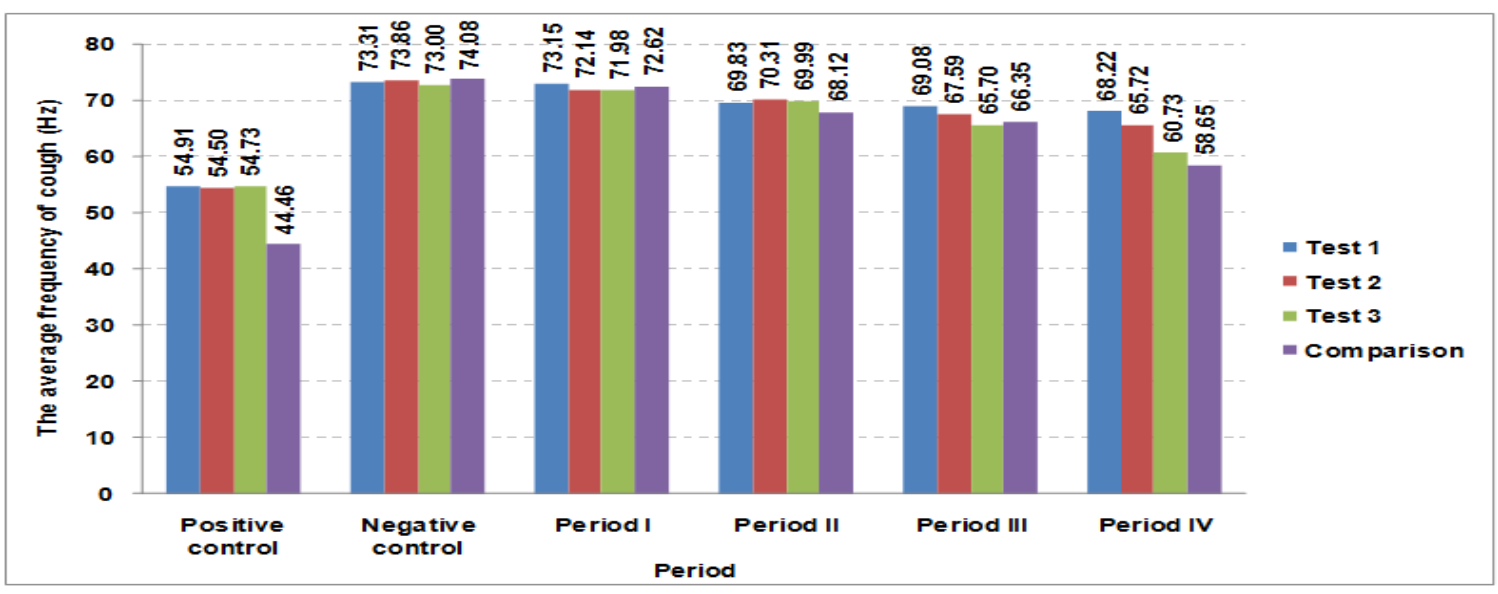

Fig. 3: Changes in the respiratory of guinea pigs cough with n-hexane fraction. 1) Positive control (CMC Na. 1\%); 2) negative control (Citrit acid 10\%); 3) period I (Test extract+induction in the min 0-15); 4) period II (Test extract+induction in the min 15-30); 5) period III (Test extract+induction in the min to 30-45); 4) period IV (Test extract+induction in the min to 45-60)

The ratio of intensity of artificial breathing patterns guinea pig cough water fraction groups of sage leaves at a dose of $4,58 \mathrm{mg} / \mathrm{kg}$ bw, a dose of $9.17 \mathrm{mg} / \mathrm{kg}$ bw violence did not differ significantly $(\mathrm{P}<0.05)$, whereas in fraction ethyl acetate and n-hexane dose of $4,58 \mathrm{mg} / \mathrm{kg} \mathrm{bw}$ dose of $9.17 \mathrm{mg} / \mathrm{kg} \mathrm{bw}$, and a dose of $18.35 \mathrm{mg} / \mathrm{kg}$ bw showed significantly different results $(\mathrm{P}<0.05)$, which means that the fraction and the dose can be improve the intensity of violence guinea pig cough artificial breathing pattern seen also by the improvement of the guinea pig cough intensity artificial respiration patterns ranging from the first period to fourth period of observation.

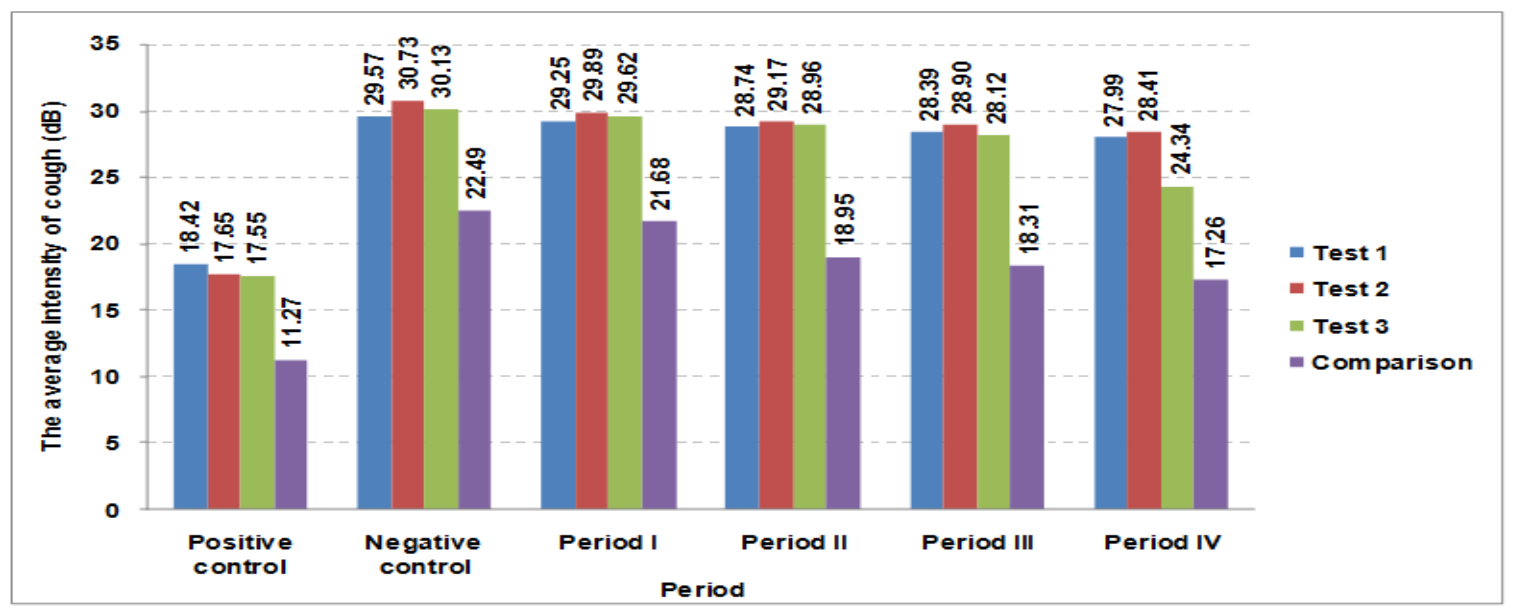

Fig. 4: Changes in the intensity of guinea pigs cough with water fraction. 1) Positive control (CMC Na. 1\%); 2) negative control (Citrit acid $10 \%)$; 3) period I (Test extract+induction in the min 0-15); 4) period II (Test extract+induction in the min 15-30); 5) period III (Test extract+induction in the min to $30-45$ ); 4) period IV (Test extract+induction in the min to 45-60)

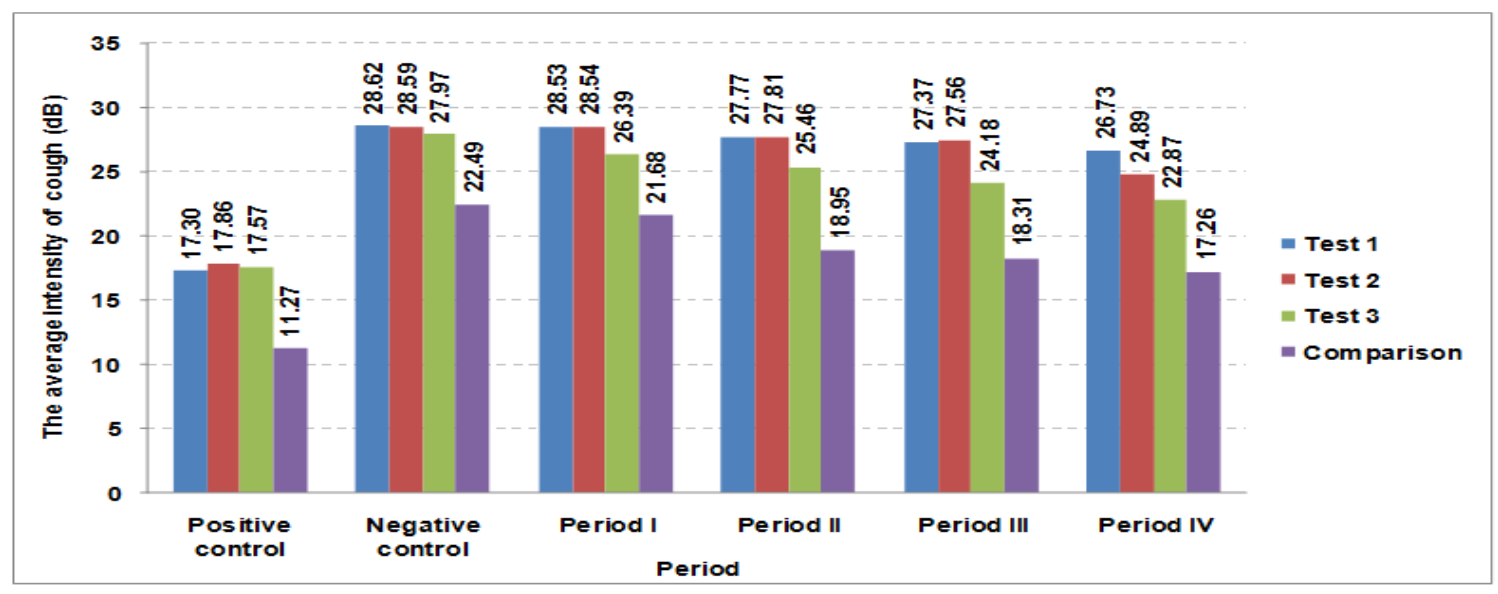

Fig. 5: Changes in the intensity of guinea pigs cough with ethyl acetat fraction. 1) Positive control (CMC Na. 1\%); 2) negative control (Citrit acid 10\%); 3) Period I (Test extract+induction in the min 0-15); 4) period II (Test extract+induction in the min 15-30); 5) period III (Test extract+induction in the min to 30-45); 4) period IV (Test extract+induction in the min to 45-60) 


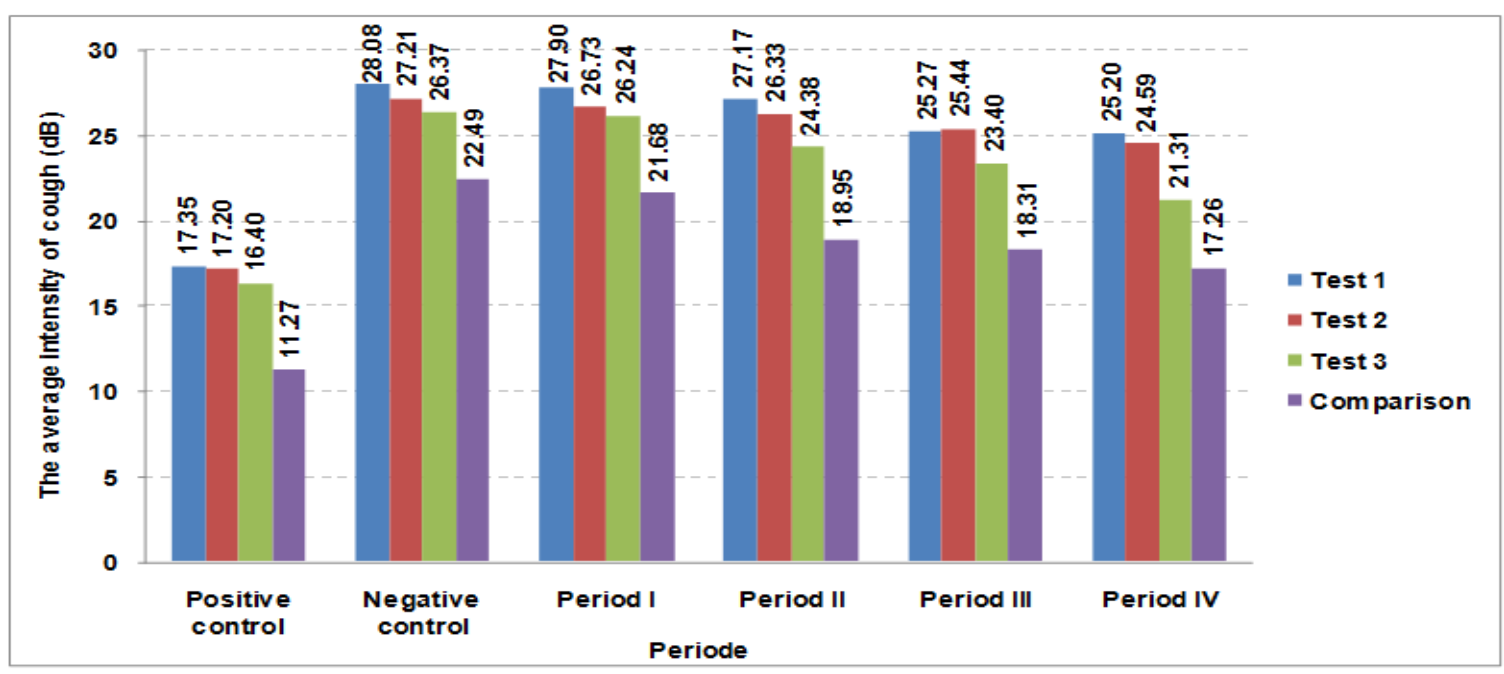

Fig. 6: Changes in the intensity of guinea pigs cough with n-hexane fraction. 1) Positive control (CMC Na. 1\%); 2) negative control (Citrit acid 10\%); 3) Period I (Test extract+induction in the min 0-15); 4) period II (Test extract+induction in the min 15-30); 5) period III (Test extract+induction in the min to $30-45$ ); 4) period IV (Test extract+induction in the min to 45-60)

\section{CONCULSION}

Recording guinea pig cough artificial respiration pattern using the program Adobe Audition 1.5can be used to evaluate the antitussive activity.

Ethanol extract of sage (Lantana camara L.) water fraction (dose of $9.17 \mathrm{mg} / \mathrm{kg} \mathrm{bw}$, dose $18.35 \mathrm{mg} / \mathrm{kg} \mathrm{bw}$ ), fraction of ethyl acetate and n-hexane fraction was significantly improve the guinea pig cough frequency artificial breathing pattern. In fractions of ethyl acetate and $\mathrm{n}$-hexane dose of $9,17 \mathrm{mg} / \mathrm{kg}$ bw and doses $18,35 \mathrm{mg} / \mathrm{kg}$ bw can improve breathing pattern guinea pig intensity artificial cough was significantly $(\mathrm{p}<0.05)$.

\section{CONFLICT OF INTERESTS}

\section{Declare none}

\section{REFERENCES}

1. De Blasio, Francesco M. Cough management: a practical approach."Cough 7.1; 2011. p. 7.

2. Brooks, Stuart M. Perspective on the human cough reflex. Cough 7.1; 2011. p. 10.

3. Bent, Stephen. Herbal medicine in the United States: review of efficacy, safety, and regulation. J General Internal Med 2008;23:854-9.

4. Srivastava, Janmejai K, Eswar Shankar, Sanjay Gupta. Chamomile: a herbal medicine of the past with bright future. Mol Med Reports 2010;3:895.

5. Swamy, Mallappa Kumara, Sinniah, Uma Rani, Akhtar, Mohd Sayeed. In vitro pharmacological activities and GC-MS analysis of different solvent extracts of Lantana camara leaves collected from tropical region of Malaysia. J. Evidence-Based Complementary Altern Med 2015. http://dx.doi.org/10.1155/ $2015 / 506413$
6. Verdeguer, Mercedes, Blazquez, M Amparo, Boira, Herminio. Phytotoxic effects of lantana camara, eucalyptus camaldulensis and eriocephalusafricanus essential oils in weeds of mediterranean summer crops. Biochem Systematics Ecol 2009;37:362-9.

7. Ganjewala, Deepak. Biochemical compositions and antibacterial activities of lantana camara plants with yellow, lavender, red and white flowers. Eur Asia J Biosci 2009;3:6977.

8. Bhakta, Deepita, Ganjewala, Deepak. Effect of leaf positions on total phenolics, flavonoids and proanthocyanidins content and antioxidant activities in Lantana camara (L). J Sci Res 2009;1:363-9.

9. Sonibare 0, Oluwadayo, Effiong I. Antibacterial activity and cytotoxicity of essential oil of Lantana camara L. leaves from Nigeria. Afr J Biotechnol 2008;7:15.

10. Ghosh, Subhalakshmi. Anti-inflammatory and anticancer compounds isolated from ventilagomadraspatana gaertn., Rubiacordifolia Linn. and Lantana camara Linn. J Pharm Pharmacol 2010;62:1158-66.

11. Pour, Badakhshan Mahdi, Sasidharan, Sreenivasan. In vivo toxicity study of Lantana camara. Asian Pacific J Trop Biomed 2011;1:230-2.

12. Prasaja Y, Soemardji AA, Sigit JI. Activity anti-ashmatic of sembung (Blumea balsamifera (L.) DC.) leaves ethanol extract based on breathing patterns of male guinea pigs. Bandung Institute of Technology. Bandung, Indonesia; 2005. p. 1.

\section{How to cite this article}

- Wa Ode Yuliastri, Andreanus Soemardji, Mus Ifaya. Antitussive activity assayof sage (Lantana camara L.) leaves based on the breathing pattern of male guinea pigs using adobe audition 1.5 program. Int J Curr Pharm Res 2017;9(5):124-127. 